\title{
Narrative reflective writing: "It got easier as I went along"
}

Gary Barkhuizen

University of Auckland

Phil Benson

University of Hong Kong

\begin{abstract}
It has been argued that narrative is a natural way of making sense of experience and that it has a particular value in fostering teachers' reflective thinking. This paper looks at these arguments critically through a study of teachers' responses to narrative writing tasks in coursework. The study focuses on the teachers' perceptions of their enjoyment, anxieties, confidence and understanding in relation to narrative writing before and after the coursework. Findings tentatively indicate that narrative writing did come naturally to most of the teachers but that their responses became more positive as they developed experience in narrative writing within a supportive environment.
\end{abstract}

KEY-WORDS: reflective writing; narrative; teacher education

\section{Introduction}

Over the past decade there has been a great deal of interest in the role of reflective thinking in teachers' professional development (FARRELL, 2008; RICHARDS; LOCKHART, 1994; SCHON, 1996) and in narrative as means of provoking teachers' reflective thinking (BARKHUIZEN, 2007; BOLTON, 2006; LYONS; LABOSKEY, 2002). This turn towards narrative as a tool for teacher reflection also reflects a broader emerging view of teachers' knowledge. According to Johnson (2006, p. 242), within the field of TESOL "narrative has emerged as a predominant means of understanding and documenting teachers' ways of knowing". Because pedagogical knowledge tends to be bound up with practical day-to-day experience, narrative seems to be an especially apt key to teachers' knowledge. Through narratives, teachers are able to "impose order and coherence on the stream of experience and work out the meaning of incidents and events in the real world" (CARTER, 1993, p, 7).

Much of the argument for the use of narratives as a professional development tool in teaching rests upon broader assumption about the centrality of stories to human life. Although she advocates narrative writing 
in the context of teacher development, Bolton (2006, p. 203) argues that "all professional and personal experience is naturally storied" and that telling and writing stories are 'prime human ways of understanding, communicating and remembering'. Polkinghorne (1988, p. 1) argues similarly that narrative is "the primary form by which human experience is made meaningful". Although the purposes of storytelling and the kinds of stories that are told vary from culture to culture, the activity of storytelling seems to be universal. Narrative researchers have also argued that the stories we tell about ourselves influence the ways in which we live our lives. As Clandinin and Connelly (2000) put it, "we live storied lives". Some researchers have argued, however, that narrative researchers may have overstated the claim for narrative as the primary means through which human beings make sense of experience. In his contribution to a recent 'state of the art' collection of papers on narrative inquiry, for example, Schiff (2006, p. 20), a narrative psychologist, suggests that in emphasizing narrative we may be "reifying a Western, arguably middle and upper class, concept as the universal mode of shaping and articulating subjective experience". In the same collection, Sartwell (2006, p. 156) suggests that narrative researchers may be guilty of "the neglect of other ways of organizing experience or the importance at times of leaving experience unorganized": meaning, culture and identity are not exclusively linguistic matters, he argues, and in so far as they are linguistic matters, they are "only sometimes or partly narratively oriented".

The notion that storytelling is a 'natural' way of making sense of our lives is, therefore, central to its use as a tool for reflective thinking in teacher development. The assumption is that teachers are natural storytellers and that they will readily take to professional development activities involving narrative. In our experience this often turns out to be the case. But recognizing that narrative is an important, but not the only, sense-making tool available to us, we may also need to recognize that teachers' dispositions towards storytelling will vary culturally and from individual to individual. Individual teachers may be more or less disposed towards stories as a means of making sense of their experiences. They are also liable to be more or less skilled in the craft of storytelling. In the light of arguments for the use of narrative as a tool for reflective thinking, therefore, two important questions arise. Does the activity of constructing narratives of teaching experiences, in fact, come naturally to teachers? And how does engagement in narrative activities affect teachers' dispositions towards and abilities in story telling? 
This article looks at these issues in the light of a study which investigated the narrative reflective writing experiences of a group of in-service language teachers during a semester-long postgraduate course, Sociolinguistics and Language Teaching, at a New Zealand university. During the course the teachers each produced a series of four written narratives. The purpose was to reflect on the content of the course in relation to their own working lives as practising language teachers. For one of the course assignments the teachers analyzed their narratives in order to explore socially-situated thematic threads in the content of the narratives and to further make meaning of their personal teaching experiences, both past and future. The analysis was integrated with the appropriate theoretical literature and concepts encountered in the course.

Gary had been teaching the course for a few years and on each occasion the teachers were required to reflect narratively in this way. After a while he wondered if this mode of reflective practice really was useful for the teachers, and he had a number of other questions: Were they coping adequately with reflective writing? Were they able to 'story' (CONNELLY; CLANDININ, 1990) their experiences? Did they have an understanding of narrative and the purpose of narrative writing? What were their affective responses to engaging with this narrative process? By reflecting narratively, were the teachers actually learning something about themselves as teachers, about the contexts in which they worked, and about their practice? Over the years teachers on the course had often remarked that they enjoyed writing the narratives and that it was a meaningful part of the course for them. Some indicated that they really did learn something new about teaching and about themselves as teachers. Some also said they would continue to write in this way (i.e., writing stories of their experiences) after the course had ended. Gary was relieved to hear such comments, but felt he needed a more systematic measure of the success of narrative reflective writing in his course, especially since he was also aware that some teachers did not perceive the writing experience so favourably. $\mathrm{He}$ wondered if it were possible to do so quantitatively, and so decided to 'experiment' using a questionnaire approach; a pre- and a post-questionnaire, distributed at the start and end of the course respectively. Details of the questionnaires are given below. 


\section{The course and assignment}

The Sociolinguistics and Language Teaching course aimed to introduce participants to concepts and issues in sociolinguistics which are relevant to their lives as prospective or practising language teachers. The course combined topics from two theoretical and research fields: (a) sociolinguistics, which, very broadly, examines the relationship between language and society, sometimes focussing more on learning about linguistic matters and sometimes more on learning about social structures, and (b) language teaching, which includes the examination of what happens in the classroom with teachers and learners, and also how these practices relate to the broader socio-political context in which the teaching and learning takes place. The combination of these two fields in the course, therefore, aimed to prompt teachers to consider and interpret the social context of their working lives. In the course, topics which were explored were those which teachers often point out are of significant relevance to their work in the classroom, school and the community. These included sociolinguistic research methodology, language maintenance and shift in multilingual communities, the negotiation of teacher and learner identities, language-in-education planning and policy, language and power, and language variation. In sum, the course attempted to raise for reflection and debate social issues which teachers find relevant and important in their teaching practice and their learning.

The 'narrative assignment', as it was called, involved each teacher producing a written narrative reflection of between 500-1000 words at four regular intervals during the 14 -week course. The instructions for writing the narratives were fairly loose and allowed flexibility in terms of both the content of the narrative and its structure. On each of the four occasions, the teachers simply asked themselves: "How does what I'm doing in the course relate to me as a language teacher?" The responses would typically be a personal account of or comment on (i.e. a story of) the teachers' experiences, past and imagined, of the social construction of language teaching. The stories take on many different shapes, some being quite literary, others following closely the Labovian structure for accounts of specific past events, or deeply personal evaluations of one's practice, or somewhat scholarly pieces critiquing a reading or commenting on a lecture topic. The tone of the writing covered a wide range from humorous, fairytale-like, intimately personal, pedestrian, and seriously academic. But what they all had in common was their focus on 
themselves as pre-service or in-service teachers and their experiences of language teaching and learning in a social context. When Gary read the narratives, he would often comment (in writing, in the margins) about some of the content, answer a question a teacher may have asked, or he would ask some of his own. His comments were neither evaluative nor extensive; merely annotations 'in passing' as he read the stories.

The assessed component of the assignment involved the teachers writing a report based on the analysis of their four narratives. The method of analysis used was not prescribed, although teachers were asked to undertake a content analysis which (a) integrated relevant literature covered and recommended in the course, and (b) which moved beyond their written texts; i.e., to consider the broader socio-political context in which their experiences and their narratives were reflexively located. They were also provided with a set of guideline questions to assist with this task. Although some of the teachers may have begun the analysis before the post-questionnaire was completed, none had been formally submitted.

\section{Participants and methodology}

There were 21 teachers in the class and all submitted both versions of the questionnaire (i.e., $\mathrm{N}=21$ ). The teachers included those who were currently teaching languages in New Zealand, as well as a number, either international students or migrants to New Zealand, who had (sometimes considerable) experience working in other countries. There was also a wide range in terms of the length of time participants had been teaching, from a few months to many years, and their ages varied from the early twenties to about the fifties. Overall, then, the participants represented a mixed group of language teachers from diverse backgrounds and with various levels of experience.

The methodology revolved entirely around the pre- and postquestionnaires; their design, administration and analysis. (See Appendix 1 for the design of the two questionnaires. Only the first question in each case is given; the other questions, which followed exactly the same format, can be found in Tables 1 and 2.) Ten questions were included in both questionnaires, each set a reflection of the other. The pre-questionnaire referred to the beginning of the narrative writing process, eliciting expectations of the experience, and the post-questionnaire asked for teachers' responses after having completed writing the four narratives. The questions covered three broad 
topics: (1) Questions 1, 2 and 5 focused on the affective dimension of narrative reflective writing, particularly teachers' levels of enjoyment, anxiety and confidence. (2) Questions 6 and 7 focused more directly on narrative, particularly the goals of narrative reflective writing and the concept of narrative itself. (3) Drawing on literature on narrative inquiry in teacher education (e.g., BARKHUIZEN, 2007; LYONS; LABOSKEY, 2002) the remaining questions include topics that relate to teachers' knowledge (Question 3), the quality and effect of reflection (4), change as a result of reflection (8), learning about teaching context (9), and the benefits of narrative reflective writing (10). Each question required a quantitative response on a five-point Likert-type scale, and allowed an open-ended comment indicating a reason for the numerical choice. Teachers were strongly encouraged to write a comment for each question, and the response to this request was excellent.

Frequencies were calculated for each question on both questionnaires, means were calculated, and a t-test (Bonferroni corrected) measured any statistically significant differences between the pre- and post-questionnaire responses. In other words, the aim was to investigate any differences between the teachers' knowledge and experience of narrative reflective writing at the start of the 14 week course and at the end.

The comments were analyzed by following some of the procedures typical of qualitative content analysis; that is, for any one question, the theme (or themes) evident in the comment was examined (see MILES; HUBERMAN, 1994) and then, firstly, correlated with the quantitative response given by the respondent, and secondly, compared with the themes in the comments made by the other respondents. In this way, it was possible to make sense of any one teacher's responses, and also, by comparing responses across teachers, to gain an understanding of the group's experience of engaging with narrative reflective writing as a whole. Although the findings for the whole range of questions are informative and interesting, we will focus on those relating specifically to narrative and narrative reflective writing $(1,2,5,6,7)$, since they address more directly our two questions introduced in the opening section of the article. The next section begins with a brief overview of the results of the remaining questions, and then a more detailed discussion of our target questions follows. 


\section{Results}

As indicated above, Questions 3, 4, 8, 9 and 10 relate to the effects of narrative reflective writing on the teachers' own practice and their theorizing about teaching in the particular contexts in which they work. Responses to these questions reveal that the narrative writing certainly benefitted them in this regard (see Table 1). Responses to Question $3(\mathrm{t}=3.21, \mathrm{df}=20$, $\mathrm{p}=0.004<0.005)$, Question $8(\mathrm{t}=4.64, \mathrm{df}=20, \mathrm{p}=0.00<0.005)$, and Question $10(\mathrm{t}=3.53, \mathrm{df}=20, \mathrm{p}=0.002<0.005)$ show statistically significant differences between the teachers pre- and post-writing experiences. Responses to Question $4(\mathrm{t}=0.237, \mathrm{df}=19, \mathrm{p}=0.815>0.005)$ and Question $9(\mathrm{t}=1.10, \mathrm{df}=19$, $\mathrm{p}=0.285>0.005)$ are not significantly different. However, this is probably because the teachers' pre-writing expectations of the benefits of reflective writing were already high. In other words, they assumed at the start of the process that the aim of the (required) exercise was to encourage them to reflect on their practice and their working contexts because this would be of some advantage to them. Furthermore, some teachers had already experienced systematic personal reflection in previous courses during their studies and so were aware of the potential benefits. Overall, then, this form of reflective writing appears to have been successful for these teachers, and its inclusion in the course is thus justified. What captured our attention as narrative researchers, however, were the questions which focused specifically on the teachers' experiences of engaging with narrative writing - both the affective dimension and their learning about what narrative and narrative writing is. We will deal with these questions in turn. 


\section{TABLE 1}

Frequency of responses to questions 3, 4, 8, 9 and $10(\mathrm{~N}=21)$.

Pre refers to the pre-questionnaire responses, and post refers to the post-questionnaire responses

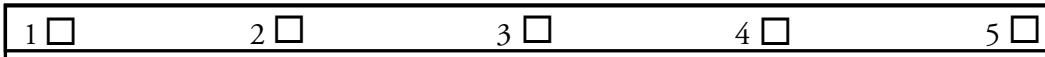

3 Pre. How much do you think writing narratives will help you to learn more about language teaching? Won't help Will help

very much 5

3 Post. How much did writing the narratives help you to learn more about language teaching? Didn't help Helped very much 4 Pre. How much do you think writing narratives will result in you reflecting on your own experiences and observations of language teaching? No reflection

\begin{tabular}{l|l|l|c} 
& & Much reflection \\
1 & 1 & 7 & 11 \\
\hline
\end{tabular}

4 Post. How much did writing the narratives result in you reflecting on your own experiences and observations of language teaching?

No reflection 3 5

Much reflection 13

8 Pre. Do you think narrative writing is going to change the way you think about language teaching? No change Change a lot 8 Post. Did narrative writing change the way you think about language teaching? No change \begin{tabular}{l|l}
1 & 3
\end{tabular} $3 \quad 10$ 107 1

9 Pre. Do you think writing the narratives will help you to understand better the particular teaching context with which you are already familiar?

Won't help

Will help

very much

$$
3
$$$$
13
$$

9 Post. Did writing the narratives help you to understand better the particular teaching context with which you are already familiar?

Didn't help

Helped

very much 9

10Pre. Do you think language teachers would benefit from the practice of narrative writing? Won't benefit Will benefit very much 5

10Post. Do you think language teachers would benefit from the practice of narrative writing? Won't benefit Will benefit very much 3 13 
Question 1Pre (Question 1 on the pre-writing questionnaire; see Table 2) asked respondents to consider how much they thought they would enjoy writing the series of narratives during the course. The purpose of this question (on both forms of the questionnaire) was to ascertain one aspect (i.e., enjoyment) of the teachers' emotional involvement with the process. This, of course, is useful information for anyone teaching a course - one hopes that one's students enjoy what they do and how they learn. But Barkhuizen and Hacker (2008; see also GOLOMBEK; JOHNSON, 2004) found that emotional investment is an inevitable and desirable condition of narrative work; it energizes participants and makes them feel that their work is legitimate. Before the writing started, at the beginning of the course, the teachers were fairly positive about their expectations of enjoyment. Three felt they would enjoy the writing very much ( 5 on the scale of 5), eleven marked option 4 on the scale and one teacher chose 3 . Some of their comments clearly reflected this positive stance. One teacher suggested that it is "good to look back" on one's teaching experience, and another said that she is "happy to write about teaching experiences". Other positive comments include: (a) reference to the "informal" style of narrative writing, which was not only "less of a burden than academic writing" but also more acceptable within the context of the course; (b) the fact that the narratives were not "marked" or assessed (although of course their analysis for the purposes of the assignment was, and this distracted some of the teachers from their enjoyment of the practice); and (c) simply, that writing the narratives had the potential to be "fun". Negative comments had to do with the fact that the narratives led to an assignment which would be formally assessed, as we've already mentioned, and that they would be time-consuming to produce. Some teachers expressed concern that they were not sure what to write.

The differences between Questions 1Pre and 1Post are statistically significant $(t=3.53, \mathrm{df}=20, \mathrm{p}=0.002<0.005)$. Twenty of the twenty-one teachers marked options 4 and 5 on the post-questionnaire (i.e., towards the enjoy very much end of the scale; see Table 2). There was thus a big shift evident from the expectation of reflective narrative writing enjoyment to the actual experience of enjoyment. The teachers' comments are revealing. Many of them refer to the surprise of how effective this 'storied' way of reflecting on teaching actually was, or "re-thinking" teaching, as one teacher put it. Others enjoyed it because it didn't take as long as they thought it would, because it was "different" from other writing typical of academic courses, and because it was 
"fun". One teacher sums up these observations: "Enjoyed tapping into my subconscious and retrieving things that I thought trivia, but realizing that I had not fully forgotten about them because of their importance". Some prewriting, expected problems did not go away, however. Some teachers found it "frustrating when not sure what to write about", a concern about content, and one teacher said that the process got "better when I stopped worrying about what they [the narratives] should be like", a stylistic or formal concern. Finally, a teacher observed that she finds "speaking is easier than writing about thoughts and emotions", a concern about the medium of storytelling.

The statistics show that there is a very big difference between the anxiety levels (see Question 2) of the teachers before and after the narrative writing experience $(\mathrm{t}=4.6, \mathrm{df}=20, \mathrm{p}=0.000<0.005)$. Nineteen of the twenty-one teachers marked options 4 and 5 on the post-questionnaire (i.e., towards the Not at all anxious end of the scale; see Table 2), whereas only six did on the pre-questionnaire. A range of factors caused the teachers' anxiety at the start of the course. These once again have to do with the content of the narratives (e.g., "not sure what to write"; "difficult to choose a story"; "don't want to write about embarrassing experiences"), their form ("not sure if doing it the 'right' way"), and the inevitable concern with the assessment of the analysis of their narratives ("no idea about how to analyze the narratives"). Many of these concerns were still evident in the teachers' comments at the end of the course, despite the statistical difference in the quantitative data. The reason for this contradiction is probably that the teachers very early on realised that whatever and however they wrote (within reason) was acceptable; they were not being judged on the content or form of their narratives by the reader (i.e., by Gary). They expressed these anxiety-generating concerns as follows: (a) the difficulty in relating their personal stories to the content of the course, (b) deciding which stories to tell when writing the narratives, (c) the possibility that some experiences written about might be considered trivial or embarrassing, and (d) that the narratives were not written well, a comment particularly from writers for whom English was not their first language (e.g., "didn't write it well grammar"). Two teachers remained anxious right till the end. Some teachers, of course, found the narratives "easy to write" or "easy to decide what to write about", and one teacher indicated that she was not at all anxious because she was telling "my own story", implying perhaps that this was less stressful than having to write a de-personalized academic essay or research report. 
TABLE 2

Frequency of responses to Questions 1,2,5,6 and $7(\mathrm{~N}=21)$.

Pre refers to the pre-questionnaire responses, and post refers to the post-questionnaire responses.

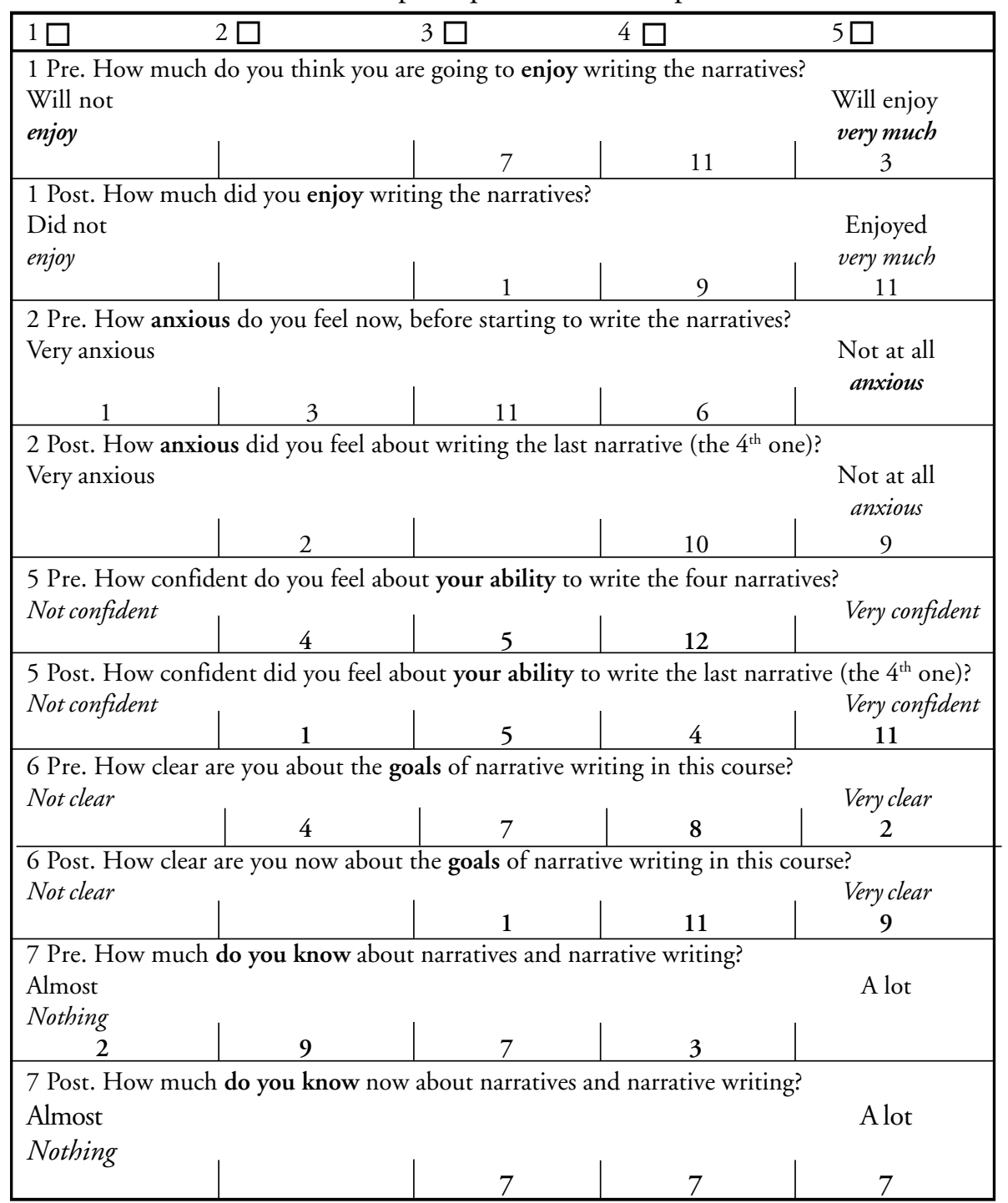

This same point was made by two of the teachers in their comments relating to Question 5Pre; one said that she was "more confident to write narratives than other writing", and the other that writing narratives is "not 
difficult because [it is one's] own experience". Confidence in narrative writing ability at the start of the course, however, was on average not very high (Mean $=3.47$ ), and the teachers comments tell us why. One teacher described herself as "not a good story teller" and "a boring writer". And another said that because English is her second language her "writing is not good" and therefore she is "not sure if [her] ideas are reflected well". One teacher anticipated that her writing would "get better with practice". The mean did not change significantly by the end of the course (Mean $=4.19 ; \mathrm{t}=2.970, \mathrm{df}=20, \mathrm{p}=0.008>0.005)$. Although there was a shift to more positive responses on the Likert scale by the end of the course (see Question 5Post), a tail remained at the Not confident end. Positive comments included those to do with (a) the clarity of what and how to write; "clear idea about what to write", "easy since knew what they should look like", "easy to write real stories", (b) teachers' improvement in narrative writing as the course progressed and as they wrote more narratives; "it got easier as I went along", "I struggled with the language a bit, but it improved for each narrative", and (c) the fact that the teachers were writing about their personal teaching experiences, a topic they felt confident about; "easy if writing about language teaching", "lots of stories to tell about teaching and learning". Those teachers who felt that they still lacked confidence at the end of the course gave a number of reasons for this. One teacher described herself as "not a great writer" and still needing "more practice to write interesting and informative narratives". Another teacher also expressed concern about the "relevance of the topic" of her narratives, and inevitably the matter of the looming assignment was mentioned again.

Question 6 addresses the purpose of narrative writing, particularly within the context of the course. As would be expected, the teachers were not very clear about the goals of narrative writing at the start of the course. They had only had a very brief introduction to the concept of narrative and the practice of narrative reflective writing before embarking on their own writing. Comments about the following are to be expected, therefore: (a) a concern with form; "not sure about the formality of writing", (b) that narrative is "somehow related to research", (c) that it relates to personal experience; "draw on personal experience regarding teaching in different contexts", and (d) that the goals will become clearer "at the end". As the course proceeded they received more guidance about narrative writing, and they also gained practice through actually doing the writing. In addition, one lecture focussed specifically on narrative inquiry as an approach to sociolinguistic research. During the lecture, the 
teachers were provided with a list of useful readings on relevant narrative research, and it was clear, when reading their assignments, that many read them. There was thus a very big difference between the teachers' pre- and postwriting responses. Twenty of the twenty-one teachers marked options 4 and 5 on the post-questionnaire (i.e., towards the Very clear end of the scale; see Table 2). This compares with ten on the pre-questionnaire. None chose options 1 and 2. Statistically the difference is significant $(t=4.37, \mathrm{df}=20$, $\mathrm{p}=0.000<0.005$ ). By the end of the course ("now that I've finished"), the teachers were able to offer their own insightful understandings of the goals of narrative writing. These included (a) learning about past and current language teaching experiences; "to make a teacher's past experiences more meaningful", "experiential way of discovering and identifying things in our teaching life", and (b) learning about oneself; "to discover myself, personal goals". One teacher sums up these goals by saying "regardless how trivial the narratives may be to me at the time of writing, by the analysis stage I see the importance of all the underlying issues within the narrative". However, there were also teachers who remained unclear about the goals. One, perhaps cynically, stated that she would be clearer when she "gets the assignment back", and another indicated that she was "not sure if the benefits experienced are the intended ones".

Question 7 (see Table 2) has the largest difference between the teachers' pre-narrative writing $($ Mean $=2.57)$ and post-writing $($ Mean $=4.00)$ scores $(t=5.84, d f=20, p=0.000<0.005)$. By the end of the course, after having written a series of four narratives and having read about and participated in a lecture on narrative and narrative research, the teachers knew a lot more about narrative work than when the course started. Comments associated with responses to Question 1Pre included rather vague statements about narratives resembling "story telling and journal/diary writing", or not knowing anything about the "theory of narrative writing". Some teachers stated that they had never written these sorts of narratives before and one said that "writing them is different from knowing what they are", implying that it may be possible to write reflective narratives without actually knowing much about what narratives are from a theoretical or experiential perspective. In contrast, by the end of the course the teachers were quite enthusiastically forthcoming with their remarks about their newly acquired knowledge of narrative. Their comments can be divided into two categories, one to do with statements about their learning and the other, reports on what they had learned. Examples of the former include, "I have learned something", and "one learns by doing". 
Examples of the latter include, "narratives are stories about teachers' teaching experiences", and comments which specify the relationship between narrative writing and "critical reflection". Two teachers made reference to the future use of narrative reflective writing, one saying that she "will stick with it" and the other indicating that she now has "a much better idea, and could give advice to those who plan to use it".

Although the difference between the responses to the pre- and postquestionnaire was statistically significant, and the comments categorically reflect this difference, the teachers' quantitative choices were evenly split between options 3, 4 and 5 (see Table 2; i.e., they did not all choose option 5). This perhaps signals some sort of ambivalence on the part of the teachers, even at the end of the course. One teacher pointed out that "I understand better than before", suggesting perhaps that she still has a lot to learn, and another teacher said that she "still needs more practice at analysis", that is, interpreting and making meaning from her writing. The next section will pull together some of the threads that have been running through this results section, and by doing so will address the two questions that we asked at the start of the article; i.e., Does the activity of constructing narratives of teaching experiences, in fact, come naturally to all teachers? And how does engagement in narrative activities affect teachers' dispositions towards and abilities in story telling?

\section{Conclusion}

As narrative researchers we are inclined to be somewhat cautious in attaching meaning to statistical results of questionnaire data, especially given the small size of the sample in this case and the known tendency for people to evaluate tasks more positively once they have been completed. Bearing this in mind, the data on the effects and benefits of narrative writing are particularly difficult to interpret. Although the teachers perceived greater benefits after the course was finished, it is possible that they were, in a sense, pre-disposed to adopt the view that narrative writing during the course they were taking would be beneficial to their teaching. The statistics certainly demonstrate this. For this reason, we have put more emphasis on the questions concerning the teachers' enjoyment, anxiety and confidence in narrative writing, and their understanding of narrative writing and its purposes in the course. Because these questions elicit personal responses to the narrative writing task, as opposed to what the teachers may have considered to be the 'correct' answers, we feel able 
to put forward some comments on the two questions raised earlier in the paper based on the results.

The first of these questions concerned teachers' predispositions towards narrative: does the activity of constructing narratives of teaching experience come naturally to all teachers? Based on the pre-questionnaire results concerning enjoyment, anxiety and confidence, we would tentatively say that most of the teachers in this study were, in fact, pre-disposed to narrative as a means of representing their experiences. Especially relevant here is the fact that although many of the students expressed anxieties and lack of confidence in their abilities, there was a strong expectation that narrative writing would be enjoyable. Their open-ended comments also suggested that anxieties and lack of confidence were not necessarily related to narrative per se, but to uncertainties about narrative writing, the ways in which the narratives would connect with what they were learning in the course and how their analyses of the narratives would be addressed and assessed. We also note from their comments that the non-native speakers of English may have been particularly anxious about narrative writing as a task; these anxieties may possibly have been related to cultural expectations about narrative writing and its role in academic coursework or they may have been, more simply, related to the teachers' concerns about their language abilities in a task that they perceived would require considerable writing skill.

Moving to the second question, which is concerned with the effects of actually writing narratives on teachers' dispositions and skills, the data seem to suggest that the effects are positive. In general, the teachers in this study reported that they enjoyed writing narratives more than they had expected, that they were less anxious and more confident when they wrote the last narrative than when they wrote the first, and that they knew more about narratives and understood their purpose in the course better. In a sense, this is not surprising, because we would expect more positive results on all of these items after the teachers had experienced narrative writing in the course. In addition, the move towards positive trends overall should also be considered in the light of the support that the teachers received during the course; a lecture and readings on narrative, as well as guiding, non-evaluative comments by the lecturer each time they wrote their narratives (both to the whole class and individually in writing on their narratives). In comparison with the post-questionnaire results, the more negative pre-questionnaire could also be interpreted in terms of fears of the unknown, which for most of the teachers dissipated once the task was 
completed. The fact remains, however, that the teachers' attitudes and their perceptions of their ability in and knowledge of narrative changed during the course (apart from the one or two 'outliers' who still responded negatively to some of the questions at the end of the course). In other words, if narrative does come naturally to teachers, narrative writing and the use of narrative to understand experiences of teaching is a craft that can be worked upon and improved.

RESUMO: Tem sido discutida a idéia de que narrativas são meios naturais de signifcar a experiência, bem como de promover a ação reflexiva dos professores. Este artigo analisa tais argumentos com um olhar crítico, por meio de um estudo das respostas dos professores às narrativas como tarefas de escrita, à guisa de atividade didática. $\mathrm{O}$ estudo enfoca as percepçōes que os professores têm acerca de suas satisfaçōes, ansiedades, confiança e entendimento em relação à escrita narrativa, antes e depois das atividades didáticas. Resultados provisórios indicam que a escrita narrativa emergiu naturalmente na maioria dos professores, mas que suas respostas tornaram-se mais positivas à medida que desenvolveram suas experiências durante a escrita narrativa, em um ambiente favorável.

PALAVRAS-CHAVE: escrita reflexiva, narrativa, educação continuada.*

\section{References}

BARKHUIZEN, G. A narrative approach to exploring context in language teaching. English Language Teaching Journal. Advance access, doi:10.1093/elt/ ccm043, 2007.

BARKHUIZEN, G.; HACKER, P. Coffee-shop narrative inquiry: implications for language teacher education. In: ANNUAL JOINT CONFERENCE OF THE LINGUISTICS SOCIETY OF SOUTHERN AFRICA, THE SOUTHERN AFRICAN APPLIED LINGUISTICS ASSOCIATION, AND THE SOUTH AFRICAN ASSOCIATION FOR LANGUAGE TEACHING, Anais. Stellenbosch, South Africa, 2008. p. 17-19.

BOLTON, G. Narrative writing: reflective enquiry into professional practice. Educational Action Research, v. 14, n. 2, p. 203-218, 2006.

* Translated by Adail Sebastião Rodrigues Júnior. 
CARTER, K. The place of story in the study of teaching and teacher education. Educational Researcher, v. 22, n. 1, p. 5-18, 1993.

CONNELLY, F.M.; CLANDININ, D.J. Stories of experience and narrative inquiry. Educational Researcher, v. 19, n. 5, p. 2-14, 1990.

CLANDININ, D. J.; CONNELLY, F. M. Narrative inquiry: experience and story in qualitative research. San Francisco: Jossey-Bass Inc, 2000.

FARRELL, T.S.C. Reflective language teaching: from research to practice. New York: Continuum, 2008.

GOLOMBEK, P.R.; JOHNSON, K.E. Narrative inquiry as a mediational space: examining emotional and cognitive dissonance in second-language teachers' development. Teachers and Teaching: Theory and Practice, v. 10, n. 3, p. 307-327, 2004.

JOHNSON, K.E. The sociocultural turn and its challenges for second language teacher education. TESOL Quarterly, v. 40, n. 1, p. 235-257, 2006.

LYONS, N.; LABOSKEY, V. K. (Ed.). Narrative inquiry in practice: advancing the knowledge of teaching. New York: Teachers College Press, 2002.

MILES, M.B.; HUBERMAN, A.M. Qualitative data analysis. $2^{\text {nd }} \mathrm{ed}$. Thousand Oaks: Sage Publications, 1994.

POLKINGHORNE, D. E. Narrative knowing and the human sciences. Albany, NY: State University of New York Press, 1988.

RICHARDS, J.C.; LOCKHART, C. Reflective teaching in second language classrooms. Cambridge: Cambridge University Press, 1994.

SARTWELL, C. Frankie, Oprah and me: The limits of narrative. Narrative Inquiry, v. 16, n. 1, p. 156-163, 2006.

SCHIFF, B. The promise (and challenge) of an innovative narrative psychology. Narrative Inquiry, v. 16, n. 1, p. 19-27, 2006.

SCHON, D.A. Educating the reflective practitioner: toward a new design for teaching and learning in the professions. San Francisco: Jossey-Bass, Inc, 1996.

Received May, 2008. Approved June 2008. 


\section{Appendix 1}

\section{Pre-questionnaire}

As part of the course you will be writing a series of four narratives. You have had a brief introduction to narrative writing. Before you actually get going, however, I would like to find out your feelings about the narrative writing process. Please answer the following questions by simply ticking the appropriate box $\square$, and giving a reason for your response. I will collate the responses and provide feedback (anonymously) to the whole class next week.

1. How much do you think you are going to enjoy writing the narratives? Will not

Will enjoy

enjoy

$1 \square$

2

$3 \square$

$4 \square$

very much

Reason for choice:

\section{Post-questionnaire}

As part of the course you have written a series of four narratives. At the start of the narrative writing process you completed a brief questionnaire on your expectations. I would now like to find out your feelings about the narrative writing process at the end of the experience. Please answer the following questions by simply ticking the appropriate box $\square$, and giving a reason for your response. I will collate the responses and provide feedback (anonymously) to the whole class next week.

1.How much did you enjoy writing the narratives?

Did not

enjoy

1 ㅁ

\section{2}

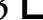

\section{Enjoyed}

very much

Reason for choice:

\footnotetext{
Reason for choice:
} 